\title{
Reforming our industrial agriculture economy
}

\section{Book review: Revolution of the Middle... and The Pursuit of Happiness by John Ikerd}

\author{
Review by Frederick Kirschenmann
}

John Ikerd (2011). Revolution of the Middle... and The Pursuit of Happiness. Available online at http://sites.google.com/site/revolutionofthemiddle/. Also available as an audio book (read by the author) at http://www.johnikerd.com/johnikerd.com/Revolution of the Middle.html.

Published online 27 July 2011

Citation: Kirschenmann, F. (2011). Reforming our industrial agriculture economy: Book review: Revolution of the Middle... and The

Pursuit of Happiness by John Ikerd. Journal of Agriculture, Food Systems, and Community Development, 1(4), 231-232.

http://dx.doi.org/10.5304/jafscd.2011.014.012

Copyright (C 2011 by New Leaf Associates, Inc.

John Ikerd, a deep-thinking economist who, among other things, taught economics at four major state universities, reminds us that he went through a mid-career transformation. As he puts it, "I spent the first half of my career as an advocate of conservative, free-market economic thinking," but the reality of the functioning economy convinced him that this "neoclassical concept of capitalism is simply not sustainable." This awareness put Ikerd on an intellectual journey, devoting his life to the question of "what we must do, individually and collectively, not only to create a

Frederick Kirschenmann is author of Cultivating an Ecological Conscience: Essays From a Farmer Philosopher. Dr. Kirschenmann is a distinguished fellow at the Leopold Center for Sustainable Agriculture at lowa State University and the president of the board at the Stone Barns Center in Picantico Hills, New York. He also serves as the president and general manager of his family's 2,600 acre (1,052 hectare) organic grain and livestock farm in North Dakota. sustainable economy but also to sustain society and humanity." His most recent book, Revolution of the Middle ... and The Pursuit of Happiness, is his most recent view of that long journey.

Much of neoclassical economic thinking is based on the money economy, which largely focuses on short-term economic return and therefore is committed to a future of unlimited economic growth. It mostly ignores the unintended consequences that, in fact, make continued growth impossible. It also focuses all of our attention on material wealth, largely ignoring our actual well-being. It is interesting that studies like those highlighted by Tim Kasser in his enlightening book, The High Price of Materialism, point out that as our material wealth has dramatically increased in the past half century, all the indicators of our well-being have actually decreased.

It is these negative consequences, along with the destruction that this extractive and exploitive 
economy is doing to our natural world, that has led Ikerd to conclude that this economy is simply not sustainable very far into the future. The alternative economy that he proposes would focus less on "stuff" and more on the "pursuit of happiness." As Ikerd points out, the Declaration of Independence, which articulated the American dream, guaranteed us the right to "life, liberty and the pursuit of happiness," not the pursuit of wealth! Ikerd's work provides the average reader with a very readable and inspiring account of how to begin our process of pursuing greater happiness and quality of life, instead of continuing our pursuit of more "stuff" at the expense of our well-being and the health of the planet. Anyone interested in that transformation should read this book.

Ikerd's vision is particularly relevant to understanding our current economic crisis. Both conservatives and liberals today seem to be focused on the question of how to get the economy back on track. But the core problem of our present economic paradigm is that our economy is, as Ikerd keeps pointing out, not sustainable. Consequently, simply trying to restore the economy to a time when it was performing a bit better will not solve our long-term problems. Herman Daly has pointed out for 30 years or more that our human economy is a subsystem of the ecosystem, and that we must therefore design it to function within the constraints of a functioning ecosystem rather than manage it like a "bubble floating in space." So until we are willing to redesign our economy so that it restores what it depletes, cleans up what it pollutes, and is adaptive to changing social, ecological, and economic cycles, we will not have a sustainable world. Changing our focus from pursuing wealth to pursuing happiness, or well-being, is therefore a necessary part of designing the new economy. Ikerd's book goes a long way toward helping us envision how we might do that.

This is, of course, no easy task. We have developed a culture that convinces us that the human species is separate from nature, that it can dominate nature, that material wealth is synonymous with well-being and that we are individually responsible for achieving such wealth regardless of the consequences to our communities or our natural world. The notion that we are "simply plain members and citizens" of the rest of the biotic community, as Aldo Leopold put it, consequently is hard for us to imagine. Yet such a cultural shift is essential to the kind of changed behavior that is essential to avoiding the potential catastrophes of climate change, diminished biodiversity and genetic diversity, and dysfunctional societies. As Herman Daly has pointed out, we harbor three great "anathemas" in our culture, ideas that we do not even want to talk about, let alone do anything about. They are (1) questioning the viability of unlimited growth, (2) entertaining the notion that there are limits to population growth, and (3) exploring the means of a more equitable distribution of wealth among the global community. All of these are part of designing an economy that enables us to "guarantee the right to life, liberty and the pursuit of happiness" to the global family. John Ikerd's book goes a long way to helping us understand how we can begin this long journey of redesigning our economy. 